\title{
Pendampingan Penyusunan Laporan Keuangan Akuntansi Pesantren
}

\author{
Valentina Monoarfa ${ }^{1}$, Ridwan Husain ${ }^{2}$, Vetty D. Pulukadang ${ }^{3}$, \\ Ahmad Dewantoro ${ }^{4}$, Regita Duda 5 \\ ${ }^{1}$ Jurusan Manajemen, Fakultas Ekonomi, Universitas Negeri Gorontalo, Jl. Jend. Sudirman \\ No. 6 Kota Gorontalo, Gorontalo 96128, Indonesia \\ E-mail: valentine@ung.ac.id ${ }^{1}$
}

Article History:

Received: 023-11-2021

Revised: 29-11-2021

Accepted: 30-11-2021

Keywords: Islamic Boarding School Accounting, Financial Report

\begin{abstract}
:
Islamic boarding school is one of the educational institutions of non-governmental non-profit religious organizations that prioritizes a service to external parties. The financial management of Islamic boarding schools still uses simple methods, accounting that has been used so far has not used financial reports that are in accordance with Islamic boarding school accounting guidelines. The purpose of this service is to provide additional knowledge to financial managers in compiling financial reports using software in order to provide transparent, accountable and accountable reporting. The method of implementing the activity is counseling, discussion and question and answer, which begins with providing knowledge about how to prepare Islamic boarding school accounting financial reports.
\end{abstract}

\section{Pendahuluan}

Penyusunan laporan keuangan pondok pesantren merupakan bentuk tanggug jawab kepada umat karena secara umum pondok pesantren dibentuk oleh dana umat. Bahkan pondok pesantren memiliki tanggung jawab untuk melaporkan laporan keuangan yang akuntabel dan bebas dari salah saji kepada pihak yang berkepentingan.

Laporan keuangan yang lengkap dari yayasan pondok pesantren terdiri atas a) Laporan posisi keuangan; b) Laporan aktivitas; c) Laporan arus kas; dan d) Catatan atas laporan keuangan. Adapun tujuan laporan keuangan yang disusun dan disajikan oleh yayasan pondok pesantren adalah:

a. Memberikan informasi tentang posisi keuangan, kinerja, arus kas dan informasi lainnya yang bermanfaat bagi pengguna laporan keuangan dalam rangka membuat keputusan ekonomi; dan

b. Bentuk pertanggungjawaban pengurus yayasan pondok pesantren atas penggunaan sumber daya yang dipercayakan kepadanya

Salah satu faktor terwujudnya penyajian laporan keuangan pondok pesantren yang sesuai dengan Pedoman Akuntansi Pesantren adalah pengetahuan staf penyusun laporan keuangan. Pengetahuan adalah ilmu dan kemampuan yang dimiliki baik dalam pencatatan, pelaporan dan dalam melakukan professional judgement atas transaksi sehingga dapat menyajikan laporan keuangan yang relevan dan sesuai dengan pedoman (Sartika dkk., 2015).

Wahyuningsih dkk. (2018) menyatakan bahwa pencatatan transaksi, penyusunan laporan keuangan Yayasan As-salam Manado tidak sesuai dengan PSAK 45, dikarenakan 
keterbatasan pengetahuan keuangan, dimana PSAK 45 merupakan bagian yang berkesinambungan dengan SAK ETAP yang digunakan sebagai acuan dalam menyusun PAP. Hasil penelitian tersebut serupa dengan penelitian dari Biduri dkk. (2019) yang menunjukkan bahwa Pondok Pesantren Darul Falah Pusat Krian belum menerapkan PSAK No.45 di dalam penyusunan laporan keuangan. Penelitian Solikhah dkk. (2019) membuktikan bahwa belum ada pondok pesantren yang menyusun laporan keuangan sesuai dengan Pedoman Akuntansi Pesantren dan PSAK No. 45, karena belum adanya pelaksanaan sistem informasi akuntansi keuangan secara optimal, dimana sistem akan terbentuk dengan adanya pengetahuan dari pengelola keuanganpengelola keuangan dalam mengelola

Pondok pesantren Al-Falah merupakan salah satu yayasan yang terletak di Gorontalo, yang didirikan pada tahun 1989, saat ini memiliki 500 santri. Pengelola keuangan di pesantren Al-Falah terbagi 2 yaitu Bendahara masuk dan Bendahara keluar dan berdasarkan hasil wawancara dari salah satu pengelola keuangan di Pesantren Al-Falah, dana yang masuk pada pesantren tersebut dari pembayar iuran santri dan dari pembayaran infaq pembangunan akan tetapi infaq tersebut milik yayasan pesantren.

Berdasarkan survey yang ada dilapangan pondok pesantren Al-Falah pengelola pesantren sudah menunjukkan adanya pengelolaan laporan keuangan dengan baik, akan tetapi permasalahan yang telah ada, bahwa penyusunan laporan keuangan masih menggunakan sisten yang sederhana, penyusunan laporan keuangan di yayasan tersebut hanya membuat laporan keuangan dalam bentuk rekapitulasi laporan pemasukan dan pengeluaran Yayasan yang penyajiannya dilakukan setiap bulan dari bulan Januari sampai dengan bulan Desember 2021. Yayasan Pondok Pesantren juga hanya membuat nama akun dengan sederhana saja dengan sepemahannya sendiri. Seharusnya laporan keuangan mengaju pada PSAK 45: Akuntansi Pesantren yang berlaku,sehingga laporan keuangan tersebut lebih mudah untuk dimengerti atau dipahami oleh pengguna laporan keuangan Yayasan

Dalam rangka upaya memberdayakan perekonomian pondok pesantren yang mampu menyusun laporan keuangan sesuai dengan aturan standar akuntansi yang berlaku di Indonesia maka ikatan akuntan indonesia dan Bank Indonesia menerbitkan pedoman akuntansi pesantren yang diharapkan nanti semua pondok pesantren dapat menjalankan laporan keuangan sesuai dengan standar akuntansi yang berlaku transparan, akuntabilitas dan efektivitas

\section{Metode}

Pendekatan deskriptif merupakan prosedur penelitian yang menghasilkan data deskriptif berupa kata-kata tertulis maupun lisan dari informan penelitian dan perilaku obyek penelitian yang diamati. Dalam penelitian ini tidak ada perlakuan yang ditambahkan atau dikurangi dalam perolehan data di lapangan. pengabdian ini berupa penyuluhan, diskusi dan tanya jawab, dimana tim pegabdian mengawali kegiatan dengan memberi pengetahuan mengenai bagaimana menyusun laporan keuangan Akuntansi Pesantren menggunakan software.

Pondok pesantren di Gorontalo yang bersedia di jadikan objek pengabdian adalah pondok pesantren Al-Falah yang terletak di JL. Kihajar Dewantoro, Tunggulo, Limboto Barat, Kabupaten Gorontalo 


\section{Hasil}

Pelaksanaan kegiatan pengabdian ini diawali dengan perkenalan dan maksud dari tujuan melakukan pengabdian kemudian memberikan pengetahuan dan pelatihan bagaimana melakukan pengelolaan laporan keuangan pondok pesantren menggunakan software serta membuat ilustrasi pelaporan keuangan sesuai PSAK 45 Akuntansi Pesantren

Hasil evalusi pelaksanaan kegiatan pengabdian kepada masyarakat yaitu kegiatan telah berjalan dengan lancar dan banyak peserta yang hadir dalam kegiatan ini. Para peserta telah mengikuti seluruh program kegiatan pengabdian mulai dari pembukaan, pendampingan penyusunan laporan keuangan menggunakan sofware, dan pedoman akuntansi pondok pesantren sesuai Standar Akuntansi Keuangan Entitas Tanpa Akuntabilitas Publik (SAK ETAP) sampai penutup.

Adapun gambaran pelaksanaan pengabdian kepada masyarakat dapat dilihat pada gambar di bawah ini:

\section{Gambar 1. Pelaksanaan Pengabdian}
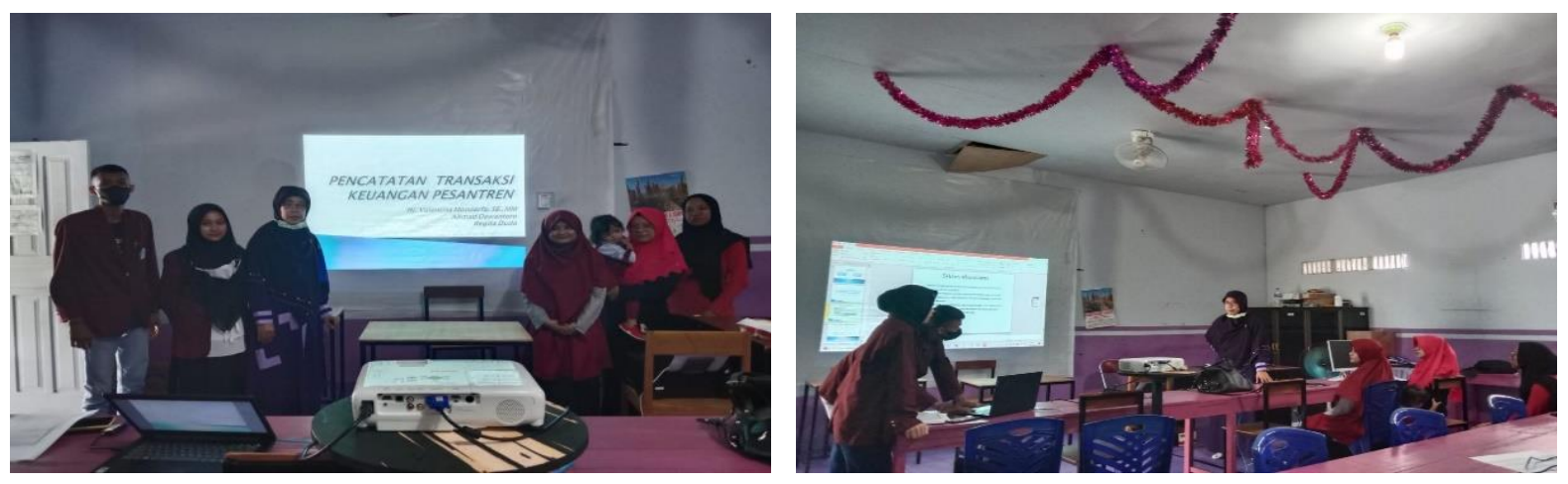

\section{Diskusi}

Pondok Pesantren adalah lembaga pendidikan yang bertujuan untuk mendalami nilai nilai keagamaan dan mempraktekannya dalam kehidupan sehari-hari (Suyono \& Wahyuni: 2014). Namun, seiring berkembangnya zaman dan ke-majuan teknologi pesantren saat ini tidak hanya mengajarkan wawasan seputar agama saja, ilmu-ilmu umum dan teknologi mulai diajarkan di pondok pesantren saat ini.

Pondok pesantren dalam hal ini dapat kita asumsikan sebagai sebuah entitas. Sebagaimana entitas, pasti memiliki visi, misi dan tujuan yang ingin dicapai. Untuk mencapai visi dan misi sebuah entitas diperlukan usaha-usaha untuk mencapai tujuan tersebut. Terutama sebuah pondok pesantren yang besar, memer-lukan pengelolaan yang baik dari berbagai aspek yang ada di pondok pesantren tersebut.

Salah satu aspek yang paling penting dalam entitas adalah aspek keuangan dan pencatatan pelaporan keuangan yang memiliki dampak besar terhadap keberlangsungan entitas tersebut. Dalam mengelola dan mencatat transaksi yang berlangsung di pondok pesantren maka diperlukan penggunaan ilmu akuntansi. Akuntansi sebagai salah satu ba gian dalam pengelolaan keuangan suatu entitas memiliki peran yang sangat penting dan krusial. Akuntansi digunakan untuk menyajikan informasi keuangan bermanfaat yang bisa dijadikan sebagai input dalam pengambilan keputusan bisnis, maka informasi keuangan harus memiliki 4 karakteristik 
relevan, andal, dapat dibandingkan, dan dapat dipahami oleh pihak pihak yang menggunakan laporan keuangan tersebut. Untuk memahami laporan keuangan dengan baik, maka diperlukan pelaporan yang sistematis logis dan mudah dianalisis.

Tuntutan terkait aspek keuangan menjadikan pesantren mengharuskan diri untuk membuat laporan keuangan sebagai bentuk pertanggungjawaban atas pengelolaan dana pesantren. Dengan demikian, setiap pesantren yang ada di Indonesia memiliki laporan keuangan.

Ikatan Akuntan Indonesia berkerja sama dengan Bank Indonesia telah menerbitkan Pedoman Akuntansi Pesantren. Pedoman ini dibuat sebagai bentuk keberpihakan IAI dan BI akan pemberdayaan ekonomi pondok pesantren agar mampu menyusun laporan keuangan sesuai dengan standar akuntansi keuangan yang berlaku umum di Indonesia. SAK yang digunakan sebagai acuan dalam penyusunan Pedoman Akuntansi Pesantren adalah Standar Akuntansi Keuangan Tanpa Akuntabilitas Publik (SAK ET-AP). Pertimbangan dalam memilih acuan kepada SAK ETAP dilandasi bahwa aset yang dikelola Pondok Pesantren relatif besar nilainya. Dimana sebagian besar aset Pondok Pesantren adalah wakaf berupa tanah.

Format penyajian atas laporan keuangan Pondok Pesantren yang diatur dalam Pedoman Akuntansi Pondok Pesantren mengacu pada PSAK 45: Pelaporan Keuangan Entitas Nirlaba. Pedoman Akuntansi Pesantren mengatur bahwa laporan keuangan lengkap yang harus disusun pondok pesantren adalah laporan keuangan, laporan aktivitas, laporan arus kas, dan catatan atas laporan keuangan. Pedoman akuntasi pesantren ini diterapkan hanya untuk pesantren yang telah berbadan hukum yayasan. Pedoman akuntansi pesantren tidak diterapkan pada badan usaha yang berbadan hukum yang dimiliki oleh pondok pesantren seperti perseroan terbatas.

Keberadaan pedoman akuntansi pondok pesantren dalam penyusunan laporan keuangan akan membantu menghasilkan laporan keuangan yang memenuhi kebutuhan informasi para pengguna laporan keuangan. Untuk itulah dilakukan kegiatan pengabdian ini di Pesantren Al-Falah yang diharapkan dengan adanya pengabdian ini dimana materi penyusunan laporan keuangan pesantren yang disesuaikan dengan pedoman atau standar yang digunakan, maka laporan keuangan yang tersedia akan memenuhi kebutuhan para penggunanya.

\section{Kesimpulan}

Pondok pesantren merupakan salah satu usaha jasa pendidikan yang berkembang pesat di Indonesia. Banyaknya kepercayaan para orang tua untuk memberikan pendidikan yang seimbang antara ilmu eksak dengan ilmu agama mendorong banyak yayasan ataupun lembaga yang mendirikan pondok pesantren. Perkambangan pondok pesantren menuntut adanya pelaporan atas pertanggungjawaban keuangan yang didukung dengan diterbikannya Pedoman Akuntansi Pesantren. Penerbitan PAP ini merupakan dukungan dari IAI dan BI karena perkembangan pondok pesantren mendukung meningkatnya ekonomi dan pendidikan bangsa.

Kegiatan pengabdian kepada masyarakat yang dilaksanakan oleh tim Fakultas Ekonomi Universitas Negeri Gorontalotelah berjalan sesuai rencana dan hasil yang dicapai adalah adanya peningkatan pemahaman mengenai penyusunan laporan keuangan menggunakan sofware yang baik di pondok pesantren dan diupayakan dilakukan perbaikan sistem dalam Pedoman pengelolaan pembayaran, pembukuan dan pencatatan (Hartono, Pedoman Pencatatan Transaksi Keuangan Pesantren, 2018). 


\section{Pengakuan/Acknowledgements}

Terima kasih kepada seluruh pihak yang telah memberikan kontribusi baik secara langsung maupun tidak langsung sehingga kegiatan pengabdian ini dapat terlaksana dengan baik. Terima kasih kepada pimpinan Pondok Pesantren Al-Falah Gorontalo yang telah memberikan kesempatan bagi pengabdi untuk melaksanakan kegiatan pengabdian ini. Semoga apa yang telah disampaikan dalam kegiatan pengabdian ini dapat memberikan manfaat bagi pengurus pesantren.

\section{Daftar Referensi}

Niati, A., Suhardjo, Y., Wijayanti, R., \& Hanifah,R. U. (2019). Pelatihan Pengelolaan Manajemen Keuangan dan Pelaporan Keuangan Akuntansi Pesantren bagi Pengelola Yayasan Pondok Pesantren X di Kota Semarang. Jurnal Surya Masyarakat, 2(1), 7679.

Rachmani, F. A. (2020). Pengaruh pengetahuan tentang pedoman akuntansi pesantren terhadap penyajian laporan keuangan pesantren. In Proceeding of National Conference on Accounting \& Finance (Vol. 2, pp. 39-46).

Pernyataan Standar Akuntansi Keuangan (PSAK). 2002. Jakarta: Salemba Empat.

Wahyuningsih, H. K. (2018). Analisis Pelaporan Keuangan Di yayasan AsSalam Manado (Berdasarkan PSAK 45 dan PSAK 101). Jurnal Kajian Ilmiah Akuntansi Fakultas Ekonomi UNTAN (KIAFE).

Hartono, P. (2018, Agustus 25). Pedoman Pencatatan Transaksi Keuangan Pesantren. . http://www.iaiglobal.or.Id/v/files/file -publikasi /Pedoman Akuntansi Pesantren 2002052018.pdf.

Halili, 2021, PENERAPAN PSAK NO. 45 PADA PENYAJIAN LAPORAN KEUANGAN YAYASAN PONDOK PESANTREN (Studi Kasus Yayasan Pondok Pesantren Miftahul Ulum Toronan Bere' Leke Desa Larangan Badung Kec. Palengaan Kab. Pamekasan) http://repository.untag-sby.ac.id/11544/8/JURNAL.pdf 